\title{
PERANCANGAN DOKUMENTASI SISTEM MANAJEMEN PADA LABORATORIUM MEKATRONIKA UNS BERDASARKAN SNI ISO/IEC 17025 : 2008
}

\author{
Aditha Capryani*1) $^{* 1}$, Fakhrina Fahma ${ }^{2)}$, dan Adrian Nur ${ }^{3)}$ \\ 1) Mahasiswa Program Studi Sarjana Teknik Industri, Fakultas Teknik, UNS, Jl. Ir. Sutami 36A, \\ Surakarta, 57126, Indonesia \\ ${ }^{2)}$ Dosen Program Studi Sarjana Teknik Industri, Fakultas Teknik, UNS, Jl. Ir. Sutami 36A, Surakarta, \\ 57126, Indonesia \\ 3) Jurusan Teknik Kimia, Fakultas Teknik, UNS, Jl. Ir. Sutami 36A, Surakarta, 57126, Indonesia
}

\begin{abstract}
This research designed of documentation management system laboratory for Mechatronics Laboratory based on SNI ISO/IEC 17025:2008 refers to documentation management system laboratory in UPT Integrated Laboratory. Mechatronics laboratory is expanding the scope of the UPT Integrated Laboratory. Design of documentation management system laboratory required to obtain accreditation from KAN. Documents were designed consisting of level 1 Quality Guidelines, level 2 Procedures, level 3 Work Instrictions, and level 4 Forms. Design of the documents were done with five stages document requirements identification, business process identification, analysis the availability of the necessary documents, designing documents, and documents verification. From the stages, are known that 10 documents level 1 need adjustments, 2 documents level 3 and 11 documents level 4 need to be designed. On documents verification, it is known that there are documents that requires improvements in the format and content. If Mechatronics Laboratory develop, then required adjustments to the documents.
\end{abstract}

Keywords: Design of Documents, Laboratory of Mechatronics UNS, Laboratory of Testing, SNI ISO/IEC 17025:2008

\section{Pendahuluan}

Saat ini persaingan antar perusahaan maupun organisasi semakin ketat. Perusahaan atau organisasi yang pada awalnya hanya bersaing pada tingkat nasional sekarang harus bersaing dalam skala yang lebih besar yaitu pada tingkat global. Perusahaan atau organisasi perlu memperhatikan dan meningkatkan mutu agar dapat bersaing di pasar global. Untuk meningkatkan mutu diperlukan adanya infrastruktur mutu.

Infrastruktur mutu terdiri dari standardisasi, penilaian kesesuaian, dan metrologi. Standardisasi, penilaian kesesuaian, dan metrologi harus saling terintegrasi agar tercipta sistem jaminan mutu yang baik.

Menurut Undang - Undang No. 20 tahun 2004 tentang Standardisasi dan Penilaian Kesesuaian, standardisasi merupakan proses merencanakan, merumuskan, menetapkan, menerapkan memberlakukan, memelihara, dan mengawasi standar yang dilaksanakan secara tertib melalui dan bekerja sama dengan semua Pemangku Kepentingan. Penilaian kesesuaian adalah kegiatan untuk menilai bahwa barang, jasa, sistem, proses, atau personal telah memenuhi persyaratan acuan. Kegiatan penilaian kesesuaian dilakukan melalui pengujian, inspeksi dan/atau sertifikasi. Pengujian merupakan satu cara untuk memeriksa atau menentukan karakteristik, kandungan dan/atau parameter yang menentukan mutu suatu produk, komponen, bahan, dan lain sebagainya (ISO/IEC 17000, 2004). Kegiatan penilaian kesesuaian dalam

\footnotetext{
*Correspondance : acapryani@gmail.com
} 
bentuk pengujian ini dilakukan oleh Laboratorium Pengujian (LP). Dalam Peraturan Kepala Badan Standardisasi Nasional Nomor 135/PER/BSN/12/2010, metrologi adalah mewujudkan pengukuran yang akurat dan terpercaya serta tertelusur ke Standar Internasional (dasar persyaratan kinerja dalam standar).

Dalam hal perumusan standar sel lithium ion sekunder, BSN melakukan kerjasama dengan UNS (Universitas Sebelas Maret Surakarta) (Badan Standardisasi Nasional [BSN], 2015). Sebagai bentuk dari kerjasama BSN dengan UNS dalam membuat standar sel lithium ion sekunder, pada tanggal 10 November 2015, UNS menandatangani MoU dengan BSN untuk Molina (Mobil Listrik Nasional). UNS dipilih untuk MoU ini karena UNS tergabung dalam tim Molina serta UNS berkomitmen dan memiliki infrastruktur dalam pengembangan sel ion lithium sekunder (baterai untuk aplikasi mobil listrik) (BSN, 2015).

Infrastruktur mutu yang kedua adalah penilaian kesesuaian. Dalam riset sel lithium ion sekunder, perlu disiapkan laboratorium pengujian untuk melaksanakan penilaian kesesuaian. Laboratorium baterai yang dimiliki UNS memiliki peluang berkembang menjadi Laboratorium Pengujian (LP) untuk sel lithium ion sekunder. Laboratorium pengujian tersebut perlu disiapkan dengan tujuan apabila SNI sel lithium ion sekunder jadi diterapkan, maka laboratorium UNS nantinya akan ditunjuk sebagai salah satu laboratorium rujukan untuk pengujian (Lembaga Penelitian dan Pengabdian Kepada Masyarakat [LPPM], 2015). Syarat untuk menjadi Laboratorium Pengujian yang berhak melaksanakan penilaian kesesuaian adalah harus sudah terakreditasi. Menurut Undang - Undang No 20 tahun 2014, badan yang berhak untuk melakukan lisensi atau akreditasi pada laboratorium di Indonesia adalah Komite Akreditasi Nasional (KAN). Laboratorium pengujian perlu terakreditasi agar hasil pengujian dapat dipertanggung jawabkan. Acuan yang digunakan oleh KAN untuk memberikan akreditasi kepada laboratorium adalah standar ISO 17025 dan telah diadopsi oleh Indonesia menjadi SNI ISO/IEC 17025:2008 (International Organization for standardization / International Electrotechnical Commission).

Laboratorium yang menerapkan ISO 17025 harus memiliki dokumentasi sistem manajemen laboratorium. Hierarki dokumentasi sistem manajemen laboratorium berdasarkan SNI ISO/IEC 17025:2008 terdiri dari 4 jenis dokumen yaitu dokumen level 1 Panduan Mutu, dokumen level 2 Prosedur, dokumen level 3 Instruksi Kerja, dan dokumen level 4 Formulir (BSN, 2015). Tabel 1 berisi hubungan dari dokumen level 1, 2, 3 dan 4.

Tabel 1. Hubungan Antar Dokumen

\begin{tabular}{|l|l|}
\hline \multicolumn{1}{|c|}{ Dokumen } & \multicolumn{1}{|c|}{ Keterangan } \\
\hline Dokumen Level 1 & $\begin{array}{l}\text { kebijakan laboratorium dan tidak boleh lepas dari klausul yang terdapat di } \\
\text { dalam ISO 17025 }\end{array}$ \\
\hline Dokumen Level 2 & $\begin{array}{l}\text { prosedur untuk menerapkan kebijakan dan persyaratan yang terdapat di dalam } \\
\text { dokumen level 1 }\end{array}$ \\
\hline Dokumen Level 3 & $\begin{array}{l}\text { berbagai instruksi untuk menjalankan kebijakan dan prosedur yang telah } \\
\text { disusun (level 1 dan level 2) }\end{array}$ \\
\hline Dokumen Level 4 & $\begin{array}{l}\text { formulir yang dibuat untuk melakukan perekaman setiap kebijakan, prosedur } \\
\text { dan instruksi yang telah ditetapkan oleh laboratorium (level 1, level 2, level 3) }\end{array}$ \\
\hline
\end{tabular}

Saat ini, UNS telah memiliki laboratorium pengujian dan kalibrasi yang terakreditasi oleh KAN. Laboratorium tersebut adalah Unit Pelayanan Teknis (UPT) Laboratorium Terpadu UNS. UPT Laboratorium Terpadu UNS terdiri dari Laboratorium Pengujian/Kalibrasi dan Laboratorium Sains Dasar. Setiap divisi laboratorium dalam UPT Laboratorium Terpadu UNS tersebut telah menerapkan SNI ISO/IEC 17025: 2008 dan sudah memiliki dokumentasi sistem manajemen laboratorium.

Dalam rangka mempercepat persiapan Laboratorium Pengujian untuk sel lithium ion sekunder, dilakukan perluasan cakupan UPT Laboratorium Terpadu UNS dengan membentuk divisi laboratorium baru yaitu Laboratorium Mekatronika UNS. Laboratorium Mekatronika 
UNS dimasukkan menjadi bagian dari UPT Laboratorium Terpadu UNS agar mempermudah dalam memperoleh akreditasi dari KAN. Laboratorium Mekatronika sebagai divisi laboratorium baru di UPT Laboratorium Terpadu UNS memerlukan dokumen yang mengacu pada dokumentasi sitem manajemen laboratorium yang ada pada UPT Laboratorium Terpadu UNS. Berkaitan dengan permasalahan tersebut diperlukan perancangan dokumentasi sistem manajemen laboratorium pada Laboratorium Mekatronika berdasarkan SNI ISO/IEC 17025: 2008 mengacu pada dokumentasi sistem manajemen laboratorium yang ada pada UPT Laboratorium Terpadu UNS.

Tujuan dilakukannya penelitian ini adalah dapat merancang dokumentasi sistem manajemen laboratorium untuk Laboratorium Mekatronika UNS sesuai dengan SNI ISO/IEC 17025: 2008 mengacu pada dokumentasi manajemen laboratorium yang ada pada UPT Laboratorium Terpadu UNS.

\section{Metode Penelitian}

Metode penelitian digunakan untuk memberi gambaran mengenai langkah-langkah penelitian yang digunakan. Penelitian dimulai dengan studi pustaka, identifikasi masalah, perumusan masalah, penentuan tujuan penelitian, pengumpulan dan pengolahan data, analisis dan interpretasi hasil, serta kesimpulan dan saran.

\section{Tahap Pengumpulan dan Pengolahan Data.}

\section{Pengumpulan Data}

Data yang digunakan terdiri dari SNI ISO/IEC 17025:2008, Dokumen Level 1- 4 UPT Laboratorium Terpadu UNS, IEC 62660-1:2010, IEC 62660-2:2010, dan spesifikasi alat pengujian sel lithium ion sekunder yang dimiliki UNS. Pengujian sel lithium ion sekunder yang dilakukan di Laboratorium Mekatronika UNS menggunakan alat Eight Channels Battery Analyzer dan menggunakan software BTS Test Control 5.3.0013 (2010.6.2). Pengujian yang dapat dilakukan dengan Eight Channels Battery Analyzer adalah penentuan kapasitas baterai, daya sel, energi sel, efisiensi sel, pengosongan paksa, dan pengisian berlebih.

\section{Pengolaha Data}

Pengolahan data dilakukan dalam beberapa tahap. Urutan tahap - tahap yang dilakukan dijelaskan pada Gambar 1.

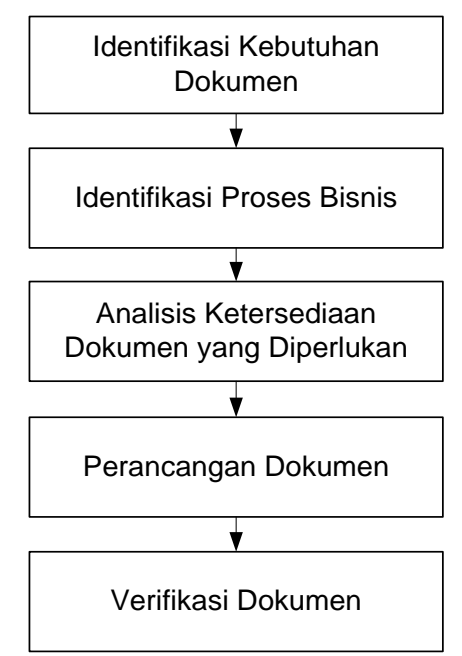

Gambar 1. Tahap Pengolahan Data

1. Melakukan identifikasi mengenai kebutuhan dokumen untuk Laboratorium Mekatronika UNS. Identifikasi kebutuhan dokumen selain mengacu pada SNI ISO/IEC 17025:2008 juga mengacu pada dokumen yang dimiliki oleh UPT Laboratorium Terpadu UNS. Dokumen terdiri dari empat level. Dari identifikasi 
yang dilakukan diperoleh data mengenai daftar dokumen yang diperlukan agar Laboratorium Mekatronika UNS dapat memenuhi SNI ISO/IEC 17025:2008.

2. Setelah dilakukan identifikasi mengenai kebutuhan dokumen, dilakukan identifikasi mengenai proses bisnis Laboratorium Mekatronika UNS agar mengetahui alur dari pelaksanaan pengujian di laboratorium tersebut. Proses bisnis ini juga mengacu pada proses bisnis yang ada di laboratorium lain di UPT Laboratorium Terpadu UNS.

3. Kemudian dilakukan analisis ketersediaan dokumen yang diperlukan Laboratorium Mekatronika UNS. Analisis ketersediaan dokumen dilakukan dengan metode checklist, yaitu dengan mencocokkan daftar dokumen yang diperlukan berdasarkan SNI ISO/IEC 17025:2008 dengan dokumen yang dimiliki oleh UPT Laboratorium Terpadu UNS.

4. Setelah diketahui ketersediaan dokumen, kemudian dilakukan perancangan dokumen yang belum tersedia dan juga dokumen yang memerlukan tambahan atau penyesuaian mengenai Laboratorium Mekatronika UNS.

5. Setelah draft dokumen selesai dibuat, dilakukan verifikasi. Verifikasi dilakukan melalui diskusi dengan Kepala UPT Laboratorium Terpadu, Kepala Divisi Bidang Mekatronika, pihak yang ikut serta dalam proyek Molina UNS perumusan SNI baterai untuk memastikan draft dokumen yang telah dibuat sudah memenuhi kebutuhan dokumen untuk Laboratorium Mekatronika UNS serta memiliki konten dan format yang benar.

\section{Hasil dan Pembahasan}

3.1 Identifikasi Kebutuhan Dokumen untuk Laboratorium Mekatronika UNS

Berdasarkan identifikasi yang telah dilakukan dengan mengacu pada elemen yang terdapat pada standar SNI ISO/IEC 17025:2008 dan dokumen yang ada pada UPT Laboratorium Terpadu UNS diketahui bahwa dokumen yang dibutuhkan oleh Laboratorium Mekatronika UNS terdiri dari 44 dokumen level 1, 44 dokumen level 2, 3 dokumen level 3, dan 59 dokumen level 4.

\subsection{Identifikasi Proses Bisnis Laboratorium Mekatronika UNS}

Proses bisnis dari Laboratorium Mekatronika UNS, yaitu pertama pertama customer mengajukan permintaan pengujian dan mengisi form permintaan pengujian, kemudian permintaan tersebut dikaji dan disetujui oleh Deputi Bidang Pengujian. Setelah menyetujui permintaan pengujian, Deputi Bidang Pengujian memberikan tugas kepada petugas pengambil barang uji untuk mengambil barang uji. Kemudian petugas pengambil barang uji akan mengambil barang uji ke tempat customer. Barang uji tersebut kemudian dibawa ke Laboratorium Mekatronika untuk dilakukan pengujian.

Barang uji yang telah dibawa oleh petugas kemudian diserahkan kepada staf administrasi pengujian/kalibrasi dan diberi kode oleh staf administrasi pengujian/kalibrasi. Barang uji yang telah diberi kode oleh staf administrasi pengujian/kalibrasi diserahkan kepada PLP (Pranata Laboratorium Pendidikan) sebagai koordinator analisis. PLP sebagai Koordinator Analisis akan mendistribusikan barang uji tersebut kepada PLP sebagai analisis untuk dilakukan pengujian. Setelah dilakukan pengujian pada barang uji, hasil dari pengujian tersebut dianalisis oleh PLP sebagai analisis kemudian hasilnya diserahkan kepada PLP sebagai koordinator analisis.

Data hasil pengujian kemudian dibawa ke penyelia untuk dilakukan validasi. Setelah dilakukan validasi kemudian data hasil pengujian tersebut diserahkan kepada staf administrasi pengujian/kalibrasi untuk dimasukkan ke dalam draft SHP (Sertifikat Hasil Pengujian). Draft SHP yang telah dibuat oleh staf administrasi pengujian/kalibrasi diserahkan kepada penyelia untuk dilakukan pemeriksaan. Draft SHP yang telah diperiksa dibawa kepada Kepala UPT Laboratorium Terpadu UNS dan Kepala Divisi Bidang Mekatronika (Ketua Laboratorium 
Mekatronika) untuk ditanda tangani. Ketua Laboratorium Mekatronika menandatangani bagian teknis (halaman 2 dan seterusnya). Setelah itu draft tersebut menjadi SHP dan diberikan kepada staf administrasi pengujian/kalibrasi kemudian didistribusikan kepada customer. Setelah menerima SHP, customer melakukan pembayaran biaya pelayanan pengujian kepada kasir / staf administrasi keuangan.

\subsection{Analisis Ketersediaan Dokumen yang Diperlukan Laboratorium Mekatronika UNS}

Analisis ketersediaan dokumen dilakukan dengan metode checklist.Tabel 2 merupakan contoh checklist ketersediaan dokumen level 1.

Tabel 2. Ketersediaan Dokumen Level 1

\begin{tabular}{|c|l|c|}
\hline No & \multicolumn{1}{|c|}{ Level 1 } & $\begin{array}{c}\text { Ketersediaan } \\
\text { Dokumen }\end{array}$ \\
\hline 1 & Ruang Lingkup & $\sqrt{ }$ \\
\hline 2 & Acuan Normatif & $\sqrt{ }$ \\
\hline 3 & Istilah dan Definisi & $\sqrt{ }$ \\
\hline
\end{tabular}

Tabel 3 merupakan jumlah dokumen yang tersedia dan jumlah dokumen yang perlu dirancang atau perlu penyesuaian pada setiap level.

Tabel 3. Jumlah Dokumen Tersedia dan Dokumen yang Perlu Dirancang

\begin{tabular}{|c|c|c|}
\hline Level & Tersedia & $\begin{array}{c}\text { Dirancang/ } \\
\text { Penyesuaian }\end{array}$ \\
\hline 1 & 44 & 10 \\
\hline 2 & 44 & - \\
\hline 3 & 3 & 2 \\
\hline 4 & 59 & 11 \\
\hline
\end{tabular}

\subsection{Rancangan Dokumen untuk Laboratorium Mekatronika UNS}

Berdasarkan daftar kebutuhan dan ketersediaan dokumen dapat diketahui daftar dokumen untuk Laboratorium Mekatronika UNS yang belum tersedia, dokumen yang sudah tersedia, dan dokumen yang sudah tersedia akan tetapi memerlukan penyesuaian. Kemudian dilakukan perancangan untuk dokumen yang belum tersedia dan dokumen yang memerlukan penyesuaian.

Dokumen yang dirancang terdiri dari dokumen level 1, 3, dan 4. Tidak dilakukan perancangan pada dokumen level 2 karena dokumen level 2 berkaitan dengan manajemen sehingga dapat digunakan untuk semua divisi laboratorium yang ada di UPT Laboratorium Terpadu. Tabel 4 merupakan daftar dokumen level 1 yang dilakukan penyesuaian dan Tabel 5 merupakan daftar dokumen level 4 yang dirancang. Sedangkan contoh dokumen yang dirancang terlampir.

Tabel 4. Daftar Dokumen Level 1 yang Dilakukan Penyesuaian

\begin{tabular}{|c|c|}
\hline Nama Dokumen & Penyesuaian \\
\hline Daftar Distribusi & penambahan pada personil laboratorium \\
\hline Profil Laboratorium & $\begin{array}{l}\text { penambahan pada alasan pentingnya keberadaan UPT } \\
\text { Laboratorium Terpadu berkaitan dengan adanya } \\
\text { penambahan Laboratorium Mekatronika }\end{array}$ \\
\hline Komitmen Kebijakan Mutu & $\begin{array}{l}\text { ditambahkan mengenai } \\
\text { sekunder yang dapat } \\
\text { dilakukan di }\end{array}$ \\
\hline Bagian 1 Ruang Lingkup & $\begin{array}{l}\text { Ditambahkan mengenai macam-macam layanan } \\
\text { pengujian sel lithium ion sekunder }\end{array}$ \\
\hline Bagian 3 Istilah dan Definisi & $\begin{array}{l}\text { Ditambahkan mengenai kemampuan UPT Laboratorium } \\
\text { Terpadu UNS }\end{array}$ \\
\hline Bagian 4.2 Sistem Manajemen & $\begin{array}{l}\text { Ditambahkan mengenai lingkup kegiatan dari UPT } \\
\text { Laboratorium Terpadu UNS }\end{array}$ \\
\hline Lampiran 1.0 Ruang Lingkup Pe & Ditambahkan mengenai bidang penguji, produk yang \\
\hline
\end{tabular}




\begin{tabular}{|l|l|}
\hline Kalibrasi & $\begin{array}{l}\text { diuji, jenis pengujian, spesifikasi metode pengujian, dan } \\
\text { rentang pengukuran dari pengujian sel lithium ion } \\
\text { sekunder di Laboratorium Mekatronika UNS. }\end{array}$ \\
\hline $\begin{array}{l}\text { Lampiran Butir 4.1.5.e dan 4.1.6.f Struktur } \\
\text { Organisasi dan Manajemen Laboratorium }\end{array}$ & $\begin{array}{l}\text { Ditambahkan personil dari Laboratorium Mekatronika } \\
\text { UNS pada bagian struktur organisasi }\end{array}$ \\
$\begin{array}{l}\text { Lampiran Bagian 4.10 Tujuan, Sasaran Mutu, } \\
\text { dan Target Kualitas }\end{array}$ & $\begin{array}{l}\text { Ditambahkan mengenai kemampuan UPT Laboratorium } \\
\text { Terpadu UNS }\end{array}$ \\
\hline $\begin{array}{l}\text { Lampiran Bagian 5.5 Daftar Peralatan } \\
\text { Laboratorium }\end{array}$ & $\begin{array}{l}\text { Ditambahkan mengenai nama peralatan standar, } \\
\text { spesifikasi, tanggal terakhir uji kalibrasi, dan keterangan } \\
\text { mengenai mesin yang digunakan untuk pengujian sel } \\
\text { lithium ion sekunder di Laboratorium Mekatronika UNS }\end{array}$ \\
\hline
\end{tabular}

Dokumen level 3 yang perlu dirancang adalah instruksi kerja alat dan instruksi kerja unjuk kerja. Dalam merancang dokumen level 3 instruksi kerja alat, selain mengacu pada dokumen dari laboratorium - laboratorium lain di UPT Laboratorium Terpadu UNS, perancangan dokumen ini juga mengacu pada manual dari alat yang digunakan untuk pengujian sel lithium ion sekunder yaitu Eight Channel Battery Analyzer. Dalam merancang dokumen level 3 instruksi kerja unjuk kerja, selain mengacu pada dokumen dari laboratorium - laboratorium lain di UPT Laboratorium Terpadu UNS, perancangan dokumen ini juga mengacu pada IEC 62660 $1: 2010$ dan IEC 62660 - $2: 2010$. Pada dokumen ini berisi mengenai instruksi kerja pengujian sel lithium ion sekunder menurut IEC 62660 - $1: 2010$ dan IEC 62660 - 2 : 2010. Dokumen level 3 ini memiliki keterkaitan dengan dokumen level 4, yaitu form catatan analisis dan form catatan pengaturan SOC. Kedua form tersebut digunakan untuk mencatatat hasil pengujian sel lithium ion sekunder.

Tabel 5. Daftar Dokumen Level 4 yang Dirancang

\begin{tabular}{|l|l|}
\hline \multicolumn{1}{|c|}{ Nama Dokumen } & \multicolumn{1}{c|}{ Keterangan } \\
\hline Form perencanaan pengambilan barang uji & $\begin{array}{l}\text { Berisi hari/tanggal pengambilan barang uji, jam } \\
\text { pengambilan barang uji, lokasi pengambilan barang uji, } \\
\text { tujuan pengambilan barang uji, personil yang ditunjuk } \\
\text { untuk mengambil barang uji, serta daftar peralatan dan } \\
\text { perlengkapan yang dibawa untuk mengambil barang uji }\end{array}$ \\
\hline Form Sertifikat Hasil Pengujian (SHP) & $\begin{array}{l}\text { Merupakan SHP untuk hasil pengujian sel lithium ion } \\
\text { sekunder di Laboratorium Mekatronika UNS }\end{array}$ \\
\hline Form permintaan pengujian & $\begin{array}{l}\text { Digunakan apabila customer ingin mengajukan } \\
\text { permintaan pengujian sel lithium ion sekunder di } \\
\text { Laboratorium Mekatronika UNS }\end{array}$ \\
\hline $\begin{array}{l}\text { Form disposisi pengambilan barang uji dari } \\
\text { kepala UPT Laboratorium Terpadu UNS } \\
\text { kepada Koordinator Penanganan Contoh } \\
\text { Uji/Barang Uji }\end{array}$ & $\begin{array}{l}\text { Merupakan disposisi kepada Koordinator Penanganan } \\
\text { Contoh Uji/Barang Uji untuk mengambil barang uji }\end{array}$ \\
\hline $\begin{array}{l}\text { Form kesepakatan pelaksanaan pengambilan } \\
\text { barang uji }\end{array}$ & $\begin{array}{l}\text { Berisi kesepakatan dari pihak Laboratorium Terpadu } \\
\text { UNS dengan customer untuk pengambilan barang uji }\end{array}$ \\
\hline Form surat tugas pengambilan barang uji & $\begin{array}{l}\text { Berisi surat tugas yang diberikan oleh deputi bidang } \\
\text { pengujian kepada petugas pengambil barang uji }\end{array}$ \\
\hline Form label tanggal kadaluarsa barang uji & Berisi tentang tanggal kadaluarsa dari barang uji \\
\hline $\begin{array}{l}\text { Form inventarisasi pengambilan barang uji dan } \\
\text { pengujian }\end{array}$ & $\begin{array}{l}\text { Berisi alat yang digunakan untuk pengambilan barang uji } \\
\text { dan pengujian di Laboratorium Mekatronika UNS }\end{array}$ \\
\hline Form riwayat penggunaan alat acuan & $\begin{array}{l}\text { Berisi riwayat dari penggunaan alat pengujian di } \\
\text { Laboratorium Mekatronika UNS }\end{array}$ \\
\hline Form penentuan SOC (State of Charge). & $\begin{array}{l}\text { Untuk mencatat hasil dari pengaturan SOC sel lithium } \\
\text { ion sekunder. }\end{array}$ \\
\hline Form catatan analisis & $\begin{array}{l}\text { Digunakan untuk mencatat data hasil pengujian sel } \\
\text { lithium ion sekunder }\end{array}$ \\
\hline
\end{tabular}

\subsection{Verifikasi Dokumen}

Verifikasi dokumen digunakan untuk memverifikasi draft dokumen level 1, level 3, dan level 4 yang telah dibuat. Verifikasi dokumen untuk memastikan draft dokumen yang dibuat 
sudah memenuhi kebutuhan dokumen untuk Laboratorium Mekatronika UNS serta memiliki konten dan format yang benar. Verufikasi dilakukan bersama dengan ketua UPT Laboratorium Terpadu. ketua sub Laboratorium Mekatronika UNS dan pihak yang ikut serta dalam proyek Molina UNS perumusan SNI baterai. Dari hasil FGD tersebut terdapat beberapa kesimpulan yang dapat diambil, yaitu :

1. Draft dokumen - dokumen yang telah dibuat sudah memenuhi kebutuhan dokumentasi sistem manajemen untuk Laboratorium Mekatronika UNS.

2. Format dari dokumen level 1 dan level 3 yang telah dibuat memerlukan perbaikan. Dokumen level 1 memerlukan perbaikan pada kepala dokumen dan bagian bawah dokumen, sedangkan dokumen level 3 memerlukan perbaikan pada kepala dokumen.

3. Format dari dokumen level 4 yang telah dibuat sudah sesuai dengan format dokumen yang seharusnya.

4. Isi atau konten dari dokumen level 3 sudah benar sehingga tidak memerlukan perbaikan.

5. Isi atau konten dari semua dokumen level 4 yang dirancang sudah benar sehingga tidak memerlukan perbaikan.

6. Isi atau konten dari dokumen level 1 daftar distribusi, lampiran 1.0 ruang lingkup pengujian dan kalibrasi, lampiran struktur organisasi dan manajemen laboratorium, serta lampiran daftar peralatan laboratorium sudah benar sehingga tidak memerlukan perbaikan.

7. Terdapat perbaikan isi atau konten pada 6 dokumen level 1, yaitu profil laboratorium, komitmen kebijakan mutu, bagian 1 ruang lingkup, bagian 3 istilah dan definisi, bagian 4.2 sistem manajemen, dan lampiran bagian 4.10 tujuan, sasaran mutu, dan target kualitas.

\section{Simpulan}

Berdasarkan hasil pengolahan data hingga tahap analisis yang telah dilakukan, kesimpulan yang dapat diambil antara lain:

1. Perancangan dokumentasi sistem manajemen untuk Laboratorium Mekatronika UNS dilakukan dengan lima tahap antara lain:

a. Identifikasi kebutuhan dokumen.

b. Identifikasi proses bisnis.

c. Analisis ketersediaan dokumen yang diperlukan.

d. Perancangan dokumen yang belum tersedia dan yang memerlukan penyesuaian.

e. Verifikasi dokumen yang telah dibuat.

2. Semua dokumen level 1 telah tersedia tetapi terdapat sepuluh dokumen yang perlu penyesuaian sebelum digunakan. Semua dokumen level 2 telah tersedia. Pada dokumen level 3 terdapat satu dokumen yang telah tersedia dan dua dokumen yang belum tersedia dan perlu dirancang. Pada dokumen level 4 terdapat empat puluh delapan dokumen tersedia dan sebelas dokumen yang belum tersedia dan perlu dirancang.

3. Dari verifikasi dokumen diperoleh bahwa dokumen level 1 dan level 3 memerlukan perbaikan dari segi format dan terdapat enam dokumen level 1 yang memerlukan perbaikan dari segi konten.

4. Laboratorium Mekatronika UNS akan terus berkembang sehingga jenis pengujian yang dapat dilakukan oleh laboratorium tersebut bertambah dan terdapat perubahan atau penambahan alat pengujian. Apabila hal tersebut terjadi maka diperlukan penyesuaian pada delapan dokumen level 1, dokumen level 3 instruksi kerja unjuk kerja, dokumen level 3 instruksi kerja alat, dan lima dokumen level 4. 


\section{DAFTAR PUSTAKA}

Badan Standardisasi Nasional. (2008a). SNI ISO 9000 Sistem Manajemen Mutu - Dasar Dasar dan Kosakata. Jakarta : BSN

-----. (2008b). SNI ISO/IEC 17025 Persyaratan Umum Kompetensi Laboratorium Pengujian dan Laboratorium Kalibrasi. Jakarta : BSN

-----. (2010). Peraturan Kepala Badan Standardisasi Nasional Nomor 135/PER/BSN/12/2010. Diakses dari Badan Standardisasi Nasional website : http://www.bsn.go.id/uploads/download/ssn_Tahun2010_Bab_1_sd_bab_31.pdf

-----. (2015). BSN-UNS Jajaki Kerjasama Pengembangan SNI Komponen Mobil Listrik. Diakses pada Juli 24, 2016, dari http://www.bsn.go.id/main/berita/berita_det/6198/BSN---UNS-Jajaki-KerjasamaPengembangan-SNI-Komponen-Mobil-Listrik\#.V9D971t95dh

(2015). Pelatihan Penyusunan Dokumentasi Sistem Manajemen Laboratorium (SNI ISO/IEC 17025:2008). Diakses pada Oktober 16, 2016, dari http://fliphtml5.com/iavq/mueo/basic

(2015). Pengembangan Mobil Listrik Nasional, UNS-BSN Tandatangani MoU. Diakses pada Juli 24, 2016, dari http://www.bsn.go.id/main/berita/berita det/6798/Pengembangan-Mobil-ListrikNasional--UNS-BSN-Tandatangani-MoU\#.V9jEmPB95dg

Hullihen, K., Fitzsimmons, V., \& Fisch, M. R. (2009). Establishing an ISO 17025 Compliant Laboratory at University. Journal of Modern Engineering, 10, 55-64.

International Electrotechnical Commission. (2004). IEC 17000 : Conformity Assessment -Vocabulary and General Principles.

(2010). IEC 62660-2 : Secondary Lithium-Ion Cells for The Propulsion of Electric Vehicles - Part 2: Reliability and Abuse Testing.

----. (2010). IEC 62660-1 : Secondary Lithium-Ion Cells for The Propulsion of Electric Vehicles - Part 1: Performance Testing.

Lembaga Penelitian dan Pengabdian Kepada Masyarakat. (2015). Kerjasama Pembuatan Draft SNI Komponen Mobil Listrik Universitas Sebelah Maret. Diakses pada Agustus 26, 2016, dari http://lppm.uns.ac.id/bsn-uns-jajaki-kerjasama-pembuatan-draft-snikomponen-mobil-listrik-universitas-sebelas-maret.html

Undang - Undang Republik Indonesia Nomor 20 Tahun 2014 tentang Standardisasi dan Penilaian Kesesuaian

Unit Pelayanan Teknis. (2011). Level 1 Panduan Mutu. Surakarta : Unit Pelayanan Teknis Laboratorium Terpadu Universitas Sebelas Maret.

-----. (2011). Level 2 Prosedur. Surakarta : Unit Pelayanan Teknis Laboratorium Terpadu Universitas Sebelas Maret.

-----. (2011). Level 3 Instruksi Kerja. Surakarta : Unit Pelayanan Teknis Laboratorium Terpadu Universitas Sebelas Maret.

-----. (2011). Level 4 Formulir. Surakarta : Unit Pelayanan Teknis Laboratorium Terpadu Universitas Sebelas Maret. 